\title{
Mycorrhizal fungi of exotic forest plantations
}

\author{
Peitsa Mikola \\ Department of Silviculture \\ University of Helsinki
}

\section{Introduction}

It is a well-known fact that Suillus grevillei (Boletus elegans) is to be found growing under larch (Larix spp.) and nowhere else. In late summer, sporophores of Suillus grevillei are almost invariably found in all larch forests and plantations, and even under solitary trees. The great mycologist Elias Fries already wrote: "Ubi Larix, ibi Boletus elegans".

Larch is an exotic tree species in Finland. Consequently, Suillus grevillei cannot belong to the native Finnish flora but must have arrived there with or after its hosts, Larix spp. The same applies to some other mycorrhizal fungi of larch, such as Boletinus asiaticus, B. cavipes, and Tricholoma psammopus, as well as to all the other areas where Larix spp. are grown as exotics. Likewise, mycorrhizal fungi of other forest trees have followed along with their host species when these have been cultivated outside their natural range.

Exotic forest trees are today grown extensively in many parts of the world, particularly in the tropics and subtropics. Systematic trials with exotic species have been conducted since the last century (see Streets 1962), and large-scale afforestations were started in some countries, such as New Zealand and Chile, as long ago as 1920's. According to the FAO Secretariat (1967), there are today some 80 million hectares of forest plantations in the world, a great many consisting of exotic species. New Zealand, for instance, has 0.46 mill. ha of plantations, Australia 0.3 mill. ha,
South Africa 0.92 mill. ha, and Chile 0.35 mill. ha. In all these countries the main species of plantations are pines (mainly Pinus radiata of California, P. elliottii of Florida, and $P$. patula of Mexico), although the indigenous floras of these areas include no species belonging to the Pinaceae family. Australian eucalypts (Eucalyptus spp.) which have ectotrophic mycorrhizae are also extensively grown outside their natural range, in Africa, Asia, and South America.

The aim of this article is to review the fungal flora of exotic forest plantations and to discuss the possible modes of immigration of exotic mycorrhizal fungi. ${ }^{1}$ )

\section{Mycorrhizal fungi of exotic plantations}

Local lists of fungi fruiting in exotic coniferous plantations have been published by Birch (1937) and Rawlings (1950) for New Zealand, Purnell (1957) for Victoria (Australia), Spegazzini (see references in Singer 1950) for South America, and others. Some data from these lists, supplemented with personal communications and my own field observations, are summarized in Table 1 . In addition to the fungi listed, a great number of species of Cortinarius, Inocybe, Lactarius, Russula, Tricholoma, and other genera have been described from exotic plantations (Singer 1950, and others). The fungal flora of

1) The review is based partly on the literature, partly on personal observations and discussions during a study tour round the world in 1967. The tour was sponsored by FAO. 
such plantations may also include indigenous species. Anderson (1966), for instance, found numerous European mycorrhizal fungi in Eucalyptus plantations in Italy. The majority of fungi, however, are usually exotic and, thus, the fungal population of exotic plantations differs greatly from that of the indigenous forests in the same area.

The most conspicuous and widely distributed mycorrhizal fungi of exotic coniferous plantations are several species of Suillus, $S$. grevillei being a typical example. Singer (1964) lists five species of Suillus for South America, and McNabb (1968) seven species for New Zealand, all of which have been introduced with exotic conifers. No species of Suillus belong to the native flora of the southern hemisphere.

Suillus granulatus has been desribed almost wherever any species of Pinus has been planted. It seems to be quite an adaptable species, growing in both cool boreal forests and subtropical plantations. In regard to soil $\mathrm{pH}$, too, it has a wide range; it is indigenous, for instance, in the Pinus halepensis forests on limestone rocks of the Mediterranean area and grows as an exotic under the same species on alkaline soils in the La Pampa Province of Argentina. This is somewhat surprising, because, according to pure culture experiments (Melin 1925, Modess 1941), the optimum $\mathrm{pH}$ of Suillus granulatus is between 5 and 6 and it does not grow at all at a $\mathrm{pH}$ above 7.5. Probably Suillus granulatus is a collective species, including several subspecies or even separate species with different ecological requirements. Reichert (1940), for instance, has described four closely related species in Israel, none of which is probably the true Suillus granulatus. One of these basophilous Mediterranean species, $S$. bellini, grows as an exotic in Cape Province of South Africa (Stephens \& Kidd 1953a).

Suillus luteus is another widely distributed mycorrhizal associate of exotic pine plantations. Although it is the dominant species under pine plantations in the East African Highlands (Gibson 1963), for instance, it seems to avoid very warm climates. Thus, according to Singer (1963), S. luteus is the most common species under pines in southern Chile and Argentina, whereas in the warmer area of North Argentina it is replaced by $S$. granulatus.
Suillus variegatus is apparently quite a different type and is not adaptable to warm climates. Although S. luteus and S.variegatus are equally common in the boreal pine forests, the latter species can hardly be found anywhere outside its natural range. ${ }^{1}$

Amanita is another mycorrhizal genus, several species of which have spread with exotic plantations. The most conspicuous species, A.muscaria, which forms mycorrhizae with both conifers and broad-leaved trees, is today common in New Zealand, Australia, South Africa, South America and elsewhere. It seems to avoid the most tropical elimates, however, and is unknown in East Africa, whereas it already grows in Rhodesia (I. A. S. Gibson, personal communication). According to field observations, it can probably form mycorrhizae with some indigenous trees too, at least with Nothofagus spp. in South America and New Zealand, just as some indigenous fungi may be able to form mycorrhizae with introduced trees.

Several Gasteromycetes (spp. of Rhizopogon, Scleroderma, and Pisolithus) are also common mycorrhizal associates of exotic forest plantations. The frequent occurrence of sprorophores of Rhizopogon in pine nurseries was observed quite early (Kessell 1927), and in plantations they are often found as soon as one or two years after planting. Some species of Scleroderma are known or suspected to be mycorrhizal with eucalypts, sporophores being common under exotic eucalypt plantations (Pryor 1956; Levisohn 1958; Bakshi 1966); nevertheless, the fungi may also be indigenous in the area. Pisolithus tinctorius has been described as an indigenous mycorrhizal fungus of eucalypts in Australia (Smith \& Pope 1934) and growing as an exotic under eucalypt plantations in both Israel (Reichert \& Avizohar-Hershenzon 1959) and South Africa (Stephens \& Kidd 1953 b), whereas, according to other sources, it is also indigenous in North America (Schramm 1966), where it forms mycorrhizae with pines and has been introduced into pine plantations of South America (van Suchtelen 1962).

As a whole, exotic tree plantations have greatly enriched the fungal flora of many

1) According to a recent personal communication from Dr. E. Horak, Suillus variegatus is found under pine plantations in the South Island of New Zealand. 
tropical and subtropical countries. Thus, in Sóuth America there are no indigenous species of Amanita, Cantharellus, Hygrophorus or Gomphidius, there is one indigenous species of Lactarius, and Tricholoma only occurs in the extreme south (Singer 1950). Today all these genera are represented by numerous species growing in association with introduced trees, Gomphidius, for instance, by three North American species (Singer 1964).

Not all the exotic fungi of forest plantations are necessarily mycorrhizal. Saprophytic fungi, which in nature grow on such substrates as pine needle litter, may have found a favourable environment under exotic pine plantations, too, and become naturalized.

Introduced mycorrhizal fungi may sometimes be of a considerable economic importance, improving the economy of exotic plantations. Many of the most common introduced species, such as Boletus edulis, Suillus spp. and Lactarius deliciosus, are edible, and where mushrooms grow in masses in plantations, they constitute important raw material for canning industry. Their value is increased by the fact that evidently the parasites of the mushrooms have not always been introduced with the hosts. Thus, for instance, in Australia and South America the sporophores of Lactarius deliciosus are always clean, whereas in Europe they are almost invariably infested with insect larvae. Mushrooms, in particular species of Boletus and Suillus, are also a favourite food of many game animals.

Unfortunately, some extremely poisonous fungi have also followed their mycorrhizal hosts to new areas. Thus, Amanita phalloides is a common associate of oaks in both Argentina (Singer 1950) and South Africa (Stephens \& Kidd 1953b).

\section{Modes of migration of exotic fungi}

In most countries where pines or other ectotrophic trees are not indigenous, mycorrhizal fungi probably first arrived in the roots of living tree seedlings. According to old records, early settlers often brought trees from their home countries and planted them around their new homes (see Stephens \& Kidd 1953a; Pryor 1958). Thus, large numbers of mycorrhizal seedlings of pine, oak, and other European trees were planted in
South Africa, Australia, New Zealand, and South America as long as two or three hundred years ago. When, for instance, Dutch settlers planted European oaks around their farms in South Africa, they could later observe the deadly poisonous death-cap (Amanita phalloides) fruiting under these trees.

Mycorrhizal fungi may also have arrived through botanical gardens. The first specimens of many European and North American trees were imported to botanical gardens as potted plants. Pinus radiata, for instance, was first introduced into Australia in 1857, when potted seedlings were brought from Kew Gardens to the botanical gardens of Sydney and Melbourne (Fielding 1957). Kew Gardens, in particular, has provided botanical gardens throughout the British Commonwealth with exotic plants.

Likewise commercial nurseries, to which some living plants were also imported, were founded quite early, - in South Africa, for instance, in the seventeenth century (Donald 1965). In those days there were no plant quarantine regulations restricting the import of living plants.

Because most of the immigrants, as well as the tree seedlings for botanical gardens, came from Europe, the introduced mycorrhizal fungi must be mainly of European origin, alhough the tree species of coniferous plantations are usually North American (Pinus radiata, P.elliottii, P. patula, Pseudotsuga menziesii, etc.). Several originally North American fungi, however, now also occur in the southern hemisphere, examples being Suillus lakei and S. brevipes in New Zealand (McNabb 1968) and S.brevipes in Argentina (Singer 1963).

Mycorrhizal infection may also have arrived as spores attached to imported seed. Contamination of seed with fungal spores may explain, for instance, the occurrence of Suillus grevillei under larches in some remote localities where trees have been raised from seed and no introduction of living seedlings is known (Stahl 1968). Spores of mycorrhizal fungi may also spread with air currents. So far, very little is known about the viability and germination of the spores of mycorrhizal fungi. Although spores of many mycorrhizal species are very difficult or even impossibe to germinate on synthetic media in the laboratory, numerous experiences indicate the great ease with which mycorrhizal in- 
fection spreads (Robertson 1954). In fact, special precautions are usually necessary to protect experimentally grown non-mycorrhizal seedlings from air-borne infection.

Into many countries, however, mycorrhizal fungi have been imported intentionally. Numerous examples are known in which attempts to introduce exotic pines consistently failed, until in one way or another appropriate mycorrhizal fungi were brought in (see Mikola 1969). Usually, such importation has taken place by bringing soil from a natural stand or established plantation of the respective tree species. The first intentional importation of mycorrhizal soil and artificial inoculation of tree seedlings probably took place in 1910, when, at the suggestion of Kew Gardens, soil was brought from a pine plantation in South Africa to Kenya and, by application of this inoculum, the first successful pine plantation of East Africa was established (Gibson 1963). Later on, mycorrhizal soil has been imported, for instance, to Malawi (Clements 1941), Nigeria (Madu 1967), Trinidad (Lamb 1956), Surinam (van Suchtelen 1962), and Puerto Rico (Briscoe 1959). Since nowadays plant quarantine regulations often prohibit the importation of living plants or unsterilized soil, there has sometimes been great difficulty in obtaining mycorrhizal inoculum. In fact, mycorrhizal soil has been smuggled to some countries illegally and so, of course, its importation is not well documented.

Soil inoculum contains an indiscriminate mixture of all the fungi of the stand from which it is taken, both mycorrhizal and saprophytic and even parasitic species. Thus, exotic saprophytes of forest plantations may have arrived with soil inoculum too. Because of the risk of introducing pathogens, the use of soil inoculum has been strongly criticized. Recently, several attempts have been made to introduce known species of mycorrhizal fungi in the form of spore powder, dried sporophores, or pure cultures. Although some of these experiments appear to have met with success, the practicability of these methods on a field scale is still questionable.

\section{Some conclusions}

The history of the arrival of new fungal species in various countries is not well documented. Potted tree seedlings were often transported from one country to another hundreds of years ago and consequently the most common mycorrhizal fungi were introduced to many countries long before anything was known about mycorrhizal symbiosis. It may even be difficult to decide whether a species is native or introduced. Some originally introduced fungi, saprophytic species and facultative mycorrhiza-formers in particular, today grow outside exotic plantations as well. Paxillus involutus, for instance, is quite common in the natural forests of South America but may still belong to the introduced flora (Singer 1964).

Even the present fungal flora of exotic forest plantations is very poorly known in many countries. Afforestation activity is most intensive in developing countries, where there is a great shortage of trained mycologists. Local lists and scattered observations on mushrooms of plantations are usually made by practising foresters, whereas the few mycologists, if there are any, are usually fully occupied with research on forest diseases.

In countries where planting of exotic trees dates back for a century or more, it may be impossible to trace the early migrational history of mycorrhizal fungi, and only the present situation can be recorded. On the other hand, in countries where afforestation with exotics is recent or just beginning, it is eminently desirable that records of the migration of exotic fungi should be kept up to date. Such a study is particularly recommended for botany departments of universities in these countries. 
Table 1. Mycorrhizal fungi of exotic tree plantations (p. c. = personal communication; P. M. p. o. = personal observation by the author).

Fungus Ciountry and reference Host species

Amanita muscaria

Amanita phalloides

Boletus edulis

Suillus brevipes

Suillus granulatus

Suitlus bovinus
Suillus grevillei

Australia: Purnell (1957); W. Stahl, J. F. Titze (p. c.)

New Zealand: Birch (1937)

Rawlings (1950, 1958)

South Africa: Stephens \&

Kidd (1953b)

P. M. p. o.

Rhodesia: Gibson (p. c.)

Argentina: E. A. Takacs (p. c.)

South Africa: Stephens \& Kidd (1953b)

Argentina: Singer (1950), Takacs (1961)

South Africa: Stephens \& Kidd 1953a)

P. M. p. o.

Uruguay: Singer (1964)

Australia: W. Stahl (p. c.), P. M. p. o.

South Africa: Stephens \& Kidd (1953a)

Argentina: E. A. Takacs (p. c.)

New Zealand: McNabb (1968)

Argentina: Singer (1963)

Australia: Purnell (1957), W. Stahl, J. F. Titze (p. c.), P. M. p. o.

New Zealand: McNabb (1968)

South Africa: P. M. p. o.

Argentina: R. Piterbarg (p. c.) Singer (1964), Takacs (1967)

Brazil: L. Cardoso (p. c.), P. M. p. o.

Chile: Singer (1963), P. M. p. o.

Australia: Stahl (1968), P. M. p. o.

New Zealand: Rawlings (1950, 1958), McNabb (1968)

Europe: Kreisel (1963), and others

South America: R. Singer, E. A. Takacs, H. Butin (p. c.)
Pinus spp.

Pinus, Larix, Pseudotsuga, Betula

Introduced trees

Pinus spp.

«

Cedrus deodara

Quercus spp.

$\ll$

Pinus spp.

《

$\ll$

Pinus spp.

Pinus elliottii

Pinus spp.

«

Pinus spp.

Pinus spp.

«

Pinus halepensis

Pinus spp.

$\ll$

Pinus radiata

Larix leptolepis

Larix spp.

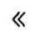

$\ll$ 
Suillus lakei

(S. amabilis)

Suillus luteus

Suillus piperatus

Leccinum duriusculum

Leccinum scabrum

Hebeloma crustuliniforme

Lactarius deliciosus

Pisolithus tinctorius

Rhizopogon luteolus
New Zealand: Rawlings (1958) McNabb (1968)

Central Europe: Moser (1967)

Australia: Purnell (1957), W. Stahl (p. c.), P. M. p. o., New Zealand: Birch (1937), Rawlings (1950, 1958), McNabb (1968)

South Africa: P. M. p. o.

Kenya: Gibson (1963)

Uganda: Brown (1963)

Chile: P. M. p. o.

Argentina: Singer (1963, 1964)

Uruguay: Takacs (1967)

New Zealand: Rawlings (1950, 1958), McNabb (1968)

South Africa: P. M. p. o.

Trinidad: Singer (1964)

South Africa: Stephens \& Kidd (1953a)

New Zealand: Rawlings (1950, 1958), McNabb (1968)

South Africa: Stephens \& Kidd (1953b), P. M. p. o.

Kenya: Gibson (1963)

Argentina: Takacs (1967)

Australia: Purnell (1957)

W. Stahl, J. F. Titze (p. c.) P. M. p. o.

South Africa: Stephens \& Kidd (1953a)

Chile: P. M. p. o.

South Africa: Stephens \& Kidd (1953b),

Zambia: N. E. Cooling (p. c.)

Israel: Reichert \& AvizoharHershenzon (1959)

Puerto Rico: P. M. p. o.

Surinam: v. Suchtelen (1962)

Australia: Purnell (1957) W. Stahl, J. F. Titze (p. c.)

New Zealand: Rawlings (1950)
Pseudotsuga menzi-

esii

$\ll$

Pinus spp.

Pinus spp.

Pinus spp.

$\ll$

$\ll$

$\ll$

$\ll$

Pinus elliottii

Pinus spp.

Pseudotsuga

Pinus spp.

«

Populus spp.

Betula spp.

Pinus spp.

«

$\ll$

Pinus spp.

Pinus radiata

Pinus spp.

Pinus radiata

Eucalyptus spp.

$\ll$

$\ll$

Pinus caribaea

$\ll$

Pinus spp.

«

Pinus radiata 
Rhizopogon roseolus

Scleroderma spp.

(S. bovista, S. vulga-

re, $S$. verrucosum,

S. flavidum)
Australia: W. Stahl, J. F. Titze

(p. c.)

New Zealand: Birch (1937)

Rawlings (1950)

South Africa: P. M. p. o.

Nigeria: P. M. p. o.

Trinidad: P. M. p. o.

New Zealand: Birch (1937)

Rawlings (1950)

Kenya: Gibson (1963)

Argentina, Uruguay: Takacs (1967)

Brazil: L. Cardoso (p. c.)
Pinus spp.

Pinus radiata

Pinus spp.

Pinus spp.

«

$\ll$

Pinus spp., Pseudotsuga

Pinus spp., Eucalyptus

spp.

Pinus radiata

Pinus spp.

Pinus spp., Eucalyptus

spp.

\section{REFERENCES}

Anderson, J. 1966. Indagini sulla micorrizia in alcune specie di eucalitto nell'Italia Centrale. - Pubbl. Centro Sper. Agr. For. VIII: $259-274$.

BAKshi, B. K. 1966. Mycorrhiza in Eucalyptus in India. - Ind. For. 92: 19-20.

Brrch, T. C. B. 1937. A synopsis of forest fungi of significance in New Zealand. - N. Z. Jour. For. 4: 109-125.

BRISGOE, C. B. 1959. Early results of mycorrhizal inoculation of pine in Puerto Rico. Ciarib. For. 20: 73-77.

Brown, J. L. 1963. Working plan for Mafuga Central Forest Reserve. - Forestry Dept., Uganda. (Stencil.)

Clements, J. B. 1941. The introduction of pines into Nyasaland. - Nyasaland Agr. Quart. Jour. 1(4): 5-15.

Donald, D. G. M. 1965. A study of the history, practice and economics of forest nurseries in South Africa. - Ann. Univ. v. Stellenbosch 40A, 1.

FAO Secretariat. 1967. Actual and potential role of man-made forests in the changing world pattern of wood consumption. - FAO World Symposium on Man-made Forests, Documents 1: 4-50.

Fielding, J. M. 1957. Introduction of Pinus radiata to Australia. - Austr. For. 21: 1516.

Grbson, I. A. S. 1963. Eine Mitteilung über die Kiefernmykorrhiza in den Wäldern Kenias. - Mykorrhiza, Intern. Mykorrhizasymposium, Weimar 1960. $49-51$.

Kessell, S. L. 1927. Soil organisms. The dependence of certain pine species on a biological soil factor. - Emp. For. Jour. 6: $70-74$.

Kreisel, H. 1963. Discussion of Singer 1963. Mykorrhiza, Intern. Mykorrhizasymposium, Weimar 1960. 229-230.

LAMB, A. F. A. 1956. Exotic forest trees in Trinidad and Tobago. - Gov. Print., Trinidad and Tobago.
Levisohn, I. 1958. Mycorrhizal infection in Eucalyptus. - Emp. For. Rev. 37: 237-241.

McNabB, R. F. R: 1968. The Boletaceae of New Zealand. - N. Z. Jour. Bot. 6: 137-176.

Madu, M. 1967. The biology of ectotrophic mycorrhiza with reference to the growth of pines in Nigeria. - Obeche, Jour. of Tree Club, Univ. of Ibadan 1(3): $9-18$.

MedrN, E. 1925. Untersuchungen über die Bedeutung der Baummykorrhiza. - G. Fischer, Jena.

MrkolA, P. 1969. Mycorrhizal inoculation in afforestation. - Intern. Rev. For. Res. 3. Academic Press, New York (In print).

Modess, O. 1941. Zur Kenntnis der Mykorrhizabildner von Kiefer und Fichte. - Symb. Bot. Upsal. 5(1).

Moser, M. 1967. Die ektotrophe Ernährungsweise an der Waldgrenze. - Mitt. d. Forstl. Bundesvers.-anst. Wien, 75: 357-380.

Pryor, L. D. 1956. Chlorosis and lack of vigour in seedlings of renantherous species of $E u$ calyptus caused by lack of mycorrhiza. Proc. Linn. Soc. N. S. W. 811: 91-96.

PRYOR, L. D. 1958. How important is mycorrhiza to introduced conifers? - Austr. Jour. Sc. 20: $215-216$.

Purnell, H. 1957. Notes on fungi found in Victorian plantations. - Plantat. Techn. Pap., Foc. Comm. Victoria, 3: 9-13.

Rawlings, G. B. 1950. The mycorrhizas of trees in New Zealand forests. - For. Res. Notes, N. Z. For. Service 1: 15-17.

Rawlings, G. B. 1958. Some practical aspects of forest mycology. - Proc. N. Z. Soc. Soil Sci. 3: $41-44$.

Reichert, I. 1940. Studies on mushrooms and other fungi of the forests of Palestine. I. Boletus Boulieri Quel. and B. Bellini Ingenza. - Palest. Jour. Bot. 3: 209-224.

Reichert, I. \& Avizohar-Hershenzon, Z. 1959. A contribution to the knowledge of higher fungi of Israel. - Bull. Res. Council Israel $7 \mathrm{D}: 222-247$. 
Robertson, N. F. 1954. Studies of the mycorrhiza of Pinus silvestris. I. The pattern of development of mycorrhizal roots and its significance for experimental studies. - The New Phytol. 53: 253-283.

Schramm, J. R. 1966. Plant colonization studies on black wastes from anthracite mining in Pennsylvania. - Trans. Amer. Phil. Soc. 56 (1)

Singer, R. 1950. Die höheren Pilze Argentiniens. - Schw. Zeitschr. f. Pilzkunde 28: 181196.

Singer, R. 1963. Der Ektotroph, seine Definition, geographische Verbreitung und Bedeutung in der Forstökologie. - Mykorrhiza, Intern. Mykorrhizasymposium, Weimar 1960. $223-231$.

Singer, R. 1964 Boletes and related groups in South America. - Nova Hedwigia 7: 93 132.

Sмith, N. J. G. \& Pope, F. B. 1934. The association between the gasteromycete Polysacchum and Eucalyptus roots. - Trans. Brit. Myc. Soc. 19: 95 .
STaHL, W. 1968. Mycorrhiza fungi may be seed borne. - Inst. Forest. Austr. Newšletter 9: 11.

Stephens, E. L. \& KrDd, M. M. 1953a. Some South African edible fungi. - Longmans, Green \& Co. Cape Town.

Stephens, E. L. \& KIDD, M. M. 1953b. Some South African poisonous fungi. - Longmans, Green \& Co. Cape Town.

Streets, R. J. 1962. Exotic forest trees in the British Commonwealth. - Glarendon Press, Oxford.

van Suchtelen, M. J. 1962. Mykorrhiza bij Pinus spp. in de tropen. - Med. Landb. Hogesch. Gent 27: 1104-1106.

TAKags, E. A. 1961. Algunas especies de hongos formadores de micorrizas en arboles forestales cultivados en la Argentina. - Rev. For. Argentina 5: 80-82.

Takacs, E. A. 1967. Produccion de cultivos puros de hongos micorrizógenos en el Centro Nacional de Investigaciones Agropecuarias, Castelar. - Idia, Suppl. For. 4: 83-87.

Received 8.2. 1969

Printed 29. 10. 1969 